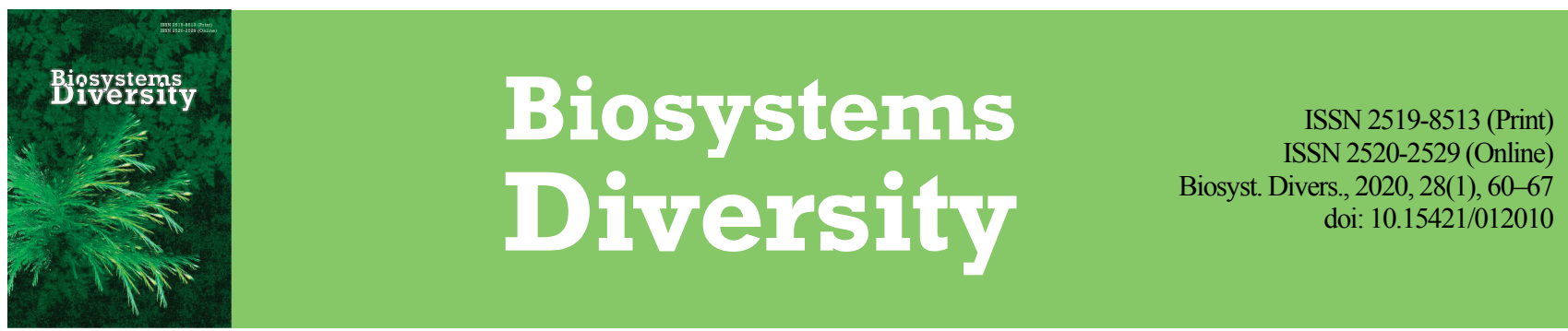

\title{
Reproductive potential of yellow water-lily (Nuphar lutea) in the conditions of lake ecosystems
}

\author{
O. A. Lebedeva*, E. A. Belyakov****, A. G. Lapirov* \\ *Papanin Institute for Biology of Inland Waters, Borok, Russia \\ **Cherepovets State University, Cherepovets, Russia
}

Article info

Received 15.02.2020

Received in revised form 10.03.2020

Accepted 11.03.2020

Papanin Institute for

Biology of Inland

Waters Russian Academy

of Sciences, 109, Borok,

152742, Russia.

Tel.: +48-547-24-042.

E-mail:

lapir@ibiw.yaroslavl.ru

Cherepovets State

University,

Lunacharsky ave., 5

Cherepovets, 162600

Russia.

Tel.: +82-025-56-597.

E-mail:

eugenybeliakov@yandex.ru

\author{
Lebedeva, O. A., Belyakov, E. A., \& Lapirov, A. G. (2020). Reproductive potential of yellow water-lily (Nuphar lutea) in the condi- \\ tions of lake ecosystems. Biosystems Diversity, 28(1), 60-67. doi:10.15421/012010
}

Nuphar lutea (L.) Sm. (Nymphaeaceae Salisb.) belongs to the category of highly active cenose-forming plants in water bodies and water flows. The material for study of morphological peculiarities and seed productivity of the fruits of this species was collected mainly in the lake ecosystems of the Central Part of European Russia and Republic of Belarus. In the study we used biomorphological and ontogenetic approaches. Seed productivity was surveyed by direct count of number of seeds in the fruit. By abundance (in descending order), the significant reliable inter-lake differences in a number of morphological parameters of the fruit fall into the following sequence: number of rays of stigma of fruit (in six pairs of lakes) $>$ length of fruit (in four pairs of lakes) $>$ diameter of the stigma of fruit (in three pairs of lakes) > diameter of fruit (in two pairs of lakes) > length of the neck of the fruit (in one pair of lakes). Intra-regional differences in certain morphological parameters of fruits (by number of rays of stigmas) were most notably manifested only in the Belarus lakes which are similar by trophic status. All the differences in the fruits' morphology could be due to differences in the habitat by the amount of nutrients in water and soil. The amount of seed productivity of the fruits from $N$. lutea varies broadly. Analysis of this parameter depending on the character of soils in which the plants grew indicated reliable results only in the case of muddy $(296 \pm 81)$ and sandy soils $(179 \pm 13)$. We determined that distribution of generative diasporas of $N$. lutea across large distances is related not only to presence of floating ability in the seeds, but also the "multi-step" process of their release: first - mericarps from fruits, and then seeds from mericarps. In the experimental conditions, most seeds directly sunk to the bed (70\%) and the rest continued to float on the surface of the water during a month. Low germination of the seeds of the water-lily in the laboratory conditions (4-6\%) with use of different means and terms of dry stratification was due to the fact that they have an organic morphophysiological intermediate type of rest. Having such a mechanism causes portioned and prolonged germination, allowing the species to survive in non-favourable conditions and accumulate generative diaspores in the soil. Despite the fact that the initial stages of ontogenesis in the laboratory and natural conditions have no significant differences, we found polyvariance in their tempo of development. First of all, this is related to different dates of transition of the plant from one age state to another. In the case of $N$. lutea, one should also note the morphological polyvariance of ontogenesis related to change in morphologic characteristics of plants depending on the water level. The obtained results give a more complete picture of the peculiarities of generative reproduction of $N$. lutea, necessary for understanding the ecosystem role of this plant and its impact on biological processes in water bodies.

Keywords: morphology of fruits; seed productivity; buoyancy of fruits; seed; germination; initial stages of ontogenesis.

\section{Introduction}

Reproduction is a multifaceted and multi-stage process which depends on different internal and external factors. Evaluation of the reproductive potential of species is based on a number of essential parameters, the main of which are the seed productivity and seed reproduction. These two processes are related to the number and morphological peculiarities of seeds, pattern of their distribution, ability to germinate and form seedlings. Solving these questions is relevant for aquatic and shoreline plants in special conditions of habitat related to different level of moisture. At the same time, studies on Nymphaea in water objects are extremely rare (Zbikowski et al., 2010).

Nuphar lutea (L.) Sm., Fl. Graec. Prodr. 1(2): 361 (1809) (family Nymphaeaceae) or yellow water lily and its related species, aquatic perennial plants distributed throughout the moderate zone of the Northern Hemisphere have attracted attention of taxonomists and ecologists for quite a while (Lippok \& Renner, 1997). Yellow water lily is a species with a Euro-Western-Asia temperate range (Tzvelev, 2000) with broad ecological valence, occurring in different aquatic ecosystem (bays of water reservoirs, ponds, oxbow lakes, backwaters, etc.) with stagnant and slowly-flowing water (Szankowski \& Kłosowski, 1999; Borysiak et al., 2011; Chernova, 2015). The species is sensitive to change in the water level (Bornette \& Puijalon, 2011; Mjelde et al., 2013). Supposedly $N$. lutea has high allelopathic potential (Elakovich \& Wooten, 1991). Yellow water lily colonizes habitats which vary from the perspective of trophic level, speed of flow, chemical composition of water and soil (Smits et al., 1988; Padgett et al., 1999; Henriot et al., 2019). It easily inhabits new habitats where it can spontaneously disperse or be reintroduced (Kaplan et al., 1998). In rivers, the canopy of submerged leaves of $N$. lutea is able to form an environment with a high content of nutrients (organic substances, total nitrogen and phosphorus) and low hydrodynamics, reminding one of conditions in flood plain lakes (Gurnell, 2014; Schoelynck et al., 2014). At the same time, growth and development of leaves of the water lily depend directly on the trophicity of the water body (Klok \& van der Velde, 2017). It is especially important to note that natural-climatic conditions of the habitat have a significant impact on the processes of generative development of plants (Chernyak, 2018).

The materials on morphology and seed productivity of the fruits, their floating ability, and germination of the seeds of yellow water lily and the initial stages of ontogenesis which are available in the literature sources (Abizov \& Tolkachev, 2016) are low-informative and fragmented (Heslop-Harrison, 1955; Dubyna, 1982; Chernova, 2013, 2015). Insignificant brief data regarding only certain diagnostic features of fruits of yellow water lily (diameter of the stigma and number of rays in it) so- 
metimes occur in a small number of guides and "Floras". At the same time, it was noted that having a good rate of germination and vitality of the seedlings, $N$. lutea is ideal for laboratory experiments (Sütfeld et al., 1996).

Therefore, the objective of our study was determining the size characteristics and seed productivity of fruits of yellow water lily from different growing locations, observation on floating ability of fruits and mericarps in laboratory conditions, as well as germination of the seeds after different pre-sowing processing and initial stages of ontogenesis of this species.

\section{Materials and methods}

Material for the study of size characteristics of fruits and seed productivity was collected in natural conditions of growth of yellow water lily in 2016 and 2019 in water bodies of Yaroslavl (the Riumnikovo
Lake - 08.07.2016, the Rybinsk Reservoir - 04.08.2016) and Tver Oblasts (the Uglich Reservoir - 09.07.2019, the Sabro Lake - 08.08.2016 and Sig Lake - 09.08.2016, Fig. 1), and also lakes of the Republic of Belarus (Skripovo, Mlynok and Vydrennik - all, 26.07.2016). In each growing location, for measurement of morphological parameters of the fruit (length and diameter of fruit, length of the neck of the fruit, diameter and number of stigma rays) and determination of the number of seeds in them (Belyakov \& Lapirov, 2019), 4-8 (12) fruits were collected.

The floating ability of fruits and mericarps of the studied species were studied in laboratory conditions. Fruits of $N$. lutea in amount of 10 (collected on 09.07.2019 in the Uglich Reservoir) were placed in glass vessels of $1.5 \mathrm{~L}$ capacity with standing tap water (the temperature of $+20 \ldots+23^{\circ} \mathrm{C}$ ). Over 30 days we monitored the process of cracking of the external coatings of the fruits, terms of release of mericarps and seeds from them.
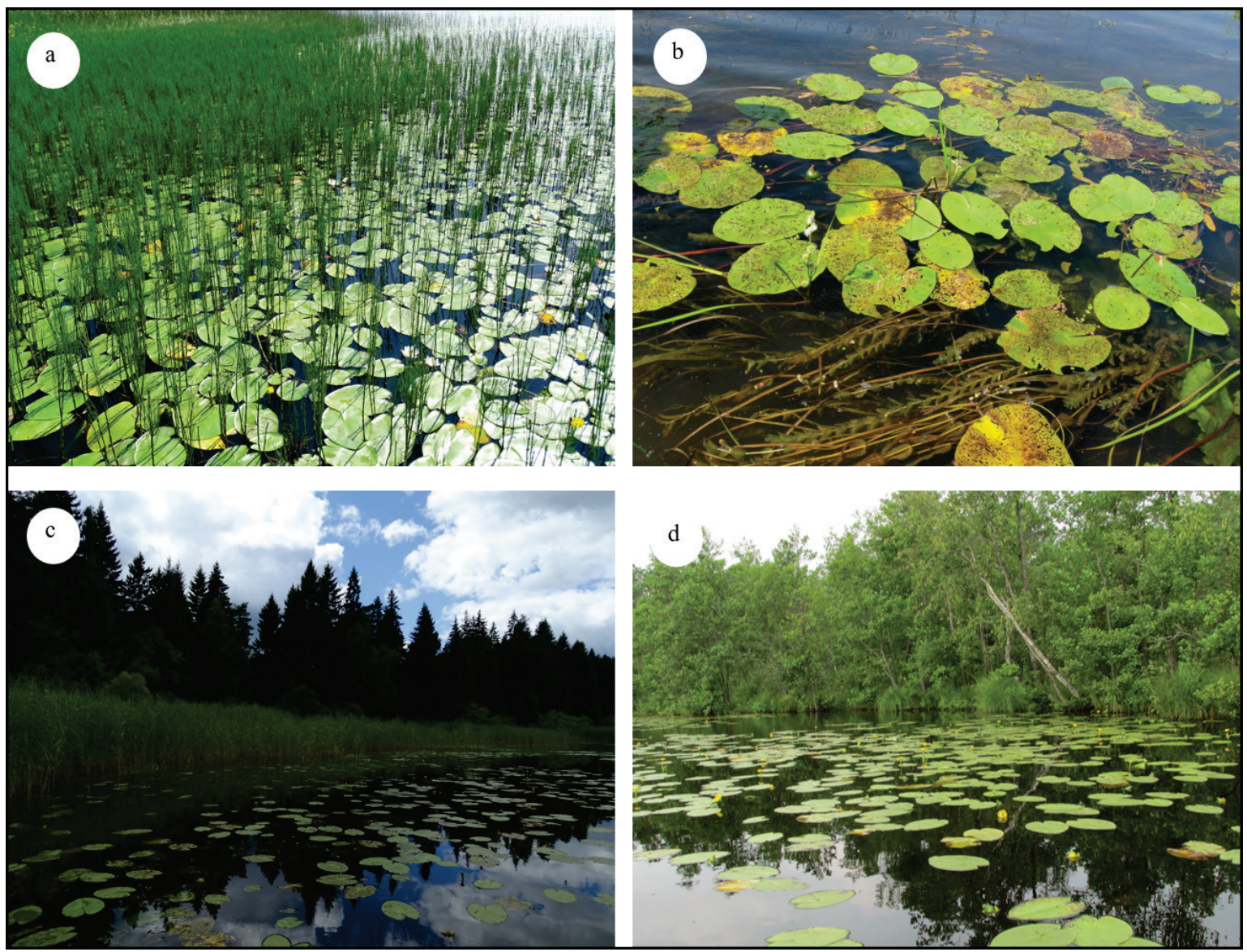

Fig. 1. Cenoses of $N$. lutea in the locations where samples were collected: $a$-Riumnikovo Lake (Yaroslavl Oblast, Rostovsky District), $b$ - the Korozhechna River, Mosalskoe village (Yaroslavl Oblast, Uglichsky District), $c$ - bay of the Uglich Reservoir in the area of Harlovo village (Kashinsky District, Tver Oblast), $d$ - Vydrenik Lake (Myadzel District, Minsk Oblast, Belarus)

Peculiarities of germination were studied on the seeds collected on 10.08.2018 in the highly overgrown lake extension of the Korozhechna River (Yaroslavl Oblast, Uglichsky district, near Masalskoe village). Some of the freshly-collected seeds were put into Petri dishes $(30$ seeds in each) on filter paper, then standing tap water $(\mathrm{pH}=8.2)$ was added, and afterwards they were exposed to a luminostat (luminance of $3200 \mathrm{~lx}$, 9/15 photoperiod (ligh/dark), the temperature ranging $+19.3 \pm 0.2{ }^{\circ} \mathrm{C}$ (morning) to $+30.0 \pm 3.0^{\circ} \mathrm{C}$ (evening)). The remaining freshly-collected seeds were divided into three equal parts: one of them was kept in Petri dishes in the laboratory conditions, the second in the refrigerator (temperature of $+2.5 \ldots+3.0^{\circ} \mathrm{C}$ ), and the third in freezer (temperature of $-24 \ldots-28^{\circ} \mathrm{C}$ ). The dry cold stratification lasted for 4,8 and 12 months.

The seeds were grown according to the general methods described in earlier works (Belyakov \& Lapirov, 2015). We determined the following main parameters (Belyakov \& Lapirov, 2015): lag-time (L) - time expressed in days between the beginning of the experiment and beginning of germination; final germination $\left(\mathrm{G}_{\text {fin }}\right.$ or $\left.\mathrm{G}\right)$ - percent of germi- nated seeds at the end of the experiment, corresponding to the term "laboratory germination" in the domestic literature (Nikolaeva et al., 1999); period of germination (P) - number of days during which the seeds germinate. The experiments were replicated three times, duration of experiments was 30 days.

The primary stages of ontogenesis of individuals of generative origin were surveyed in laboratory conditions. For this purpose, we used seedlings obtained from seeds collected in 2018 in Yaroslavl Oblast. The seedlings at the stages of opening of subulate leaf were planted from Petri dishes into desiccators 1/3 filled with sand (taken from natural growing locations), into water at the depth to $3-5 \mathrm{~cm}$. Detailed morphological analysis of the above-ground and underground spheres of the plants (we recorded appearance of initial (embryonic) root, formation of a adventitious roots, development of the first and second and the following true leaves, the length of the rosette part of the shoot) was conducted once a day over the first week of the development, once a week over the first month of the development; once in two months (by 5-10 ones) over 
the second and the following months of the development. To measure the main morphological parameters of the seedlings, we used binocular microscopes MBS-10 and MSP-2 with micrometric scales. While describing the ontogenic states and peculiarities of ontogenesis, we used the concept of discrete description and polyvariance of ontogenesis (Komarov et al., 2003; Savinykh \& Cheryomushkina, 2015; Notov \& Zhukova, 2019).

The obtained results are presented as mean value \pm standard deviation $(\mathrm{x} \pm \mathrm{SD})$. Data were analyzed in Statgraphics Centurion XVI (StatPoint Technologies, Inc., USA, 2010). Significance of the differences between the values $(P<0.05)$ were determined using method of dispersion analysis (ANOVA) in PAST (Paleontological Statistics Software Package, Norway, 1999-2019, Hammer et al., 2001). For determining the significant differences, we used the Tukey test (with extension of Copenhaver \& Holland, 1988 and Bonferonni correction).

\section{Results}

According to our data, in Central European Russia N. lutea blossoms from July to August, the fruits ripen in July-September. Fruit of the yellow water lily is oval or of egg-like conic form, with a truncated top, smooth, green. In the upper part it becomes the neck with the deeply lobed stigma disk surrounded by rays. The stigma disk is usually concave, round, rarely ellipsoid, with integral and slightly undulate margins. The size characteristics of the fruits which we collected in different water bodies are presented in Table 1 .

Table 1

Size characteristics (cm) of fruits of $N$. lutea collected in water bodies in the central part of European Russia and the Republic of Belarus $(x \pm S D, n=4-8)$

\begin{tabular}{|c|c|c|c|c|c|c|}
\hline \multicolumn{2}{|c|}{ Water bodies, region } & $\mathrm{L}_{\mathrm{fr}}, \mathrm{cm}$ & $\mathrm{D}_{\mathrm{fi}}, \mathrm{cm}$ & $\mathrm{L}_{\mathrm{nff}}, \mathrm{cm}$ & $\mathrm{D}_{\mathrm{sfr}}, \mathrm{cm}$ & $\mathrm{N}_{\mathrm{sr}}$, quantity \\
\hline \multirow{2}{*}{ Mlynok lake, Belarus $(\mathrm{n}=5)$} & mean & $3.4 \pm 0.6^{\mathrm{a}}$ & $2.8 \pm 0.3$ & $0.8 \pm 0.2$ & $1.0 \pm 0.1$ & $14.6 \pm 0.7^{\mathrm{a}}$ \\
\hline & range & $1.8-4.0$ & $2.0-1.3$ & $0.4-1.0$ & $0.8-1.2$ & $14-16$ \\
\hline \multirow{2}{*}{ Vydrennik lake, Belarus $(\mathrm{n}=8)$} & mean & $3.5 \pm 0.4^{\mathrm{b}}$ & $3.3 \pm 0.5$ & $0.8 \pm 0.2$ & $1.1 \pm 0.1$ & $14.5 \pm 1.6^{\mathrm{b}}$ \\
\hline & range & $3.0-4.5$ & $2.3-4.5$ & $0.6-1.2$ & $0.9-1.3$ & $12-17$ \\
\hline \multirow{2}{*}{ Skripovo lake, Belarus $(\mathrm{n}=8)$} & mean & $3.1 \pm 0.3$ & $3.5 \pm 0.4^{\mathrm{c}}$ & $0.9 \pm 0.1$ & $1.2 \pm 0.1^{\mathrm{c}}$ & $18.2 \pm 1.4^{\mathrm{c}}$ \\
\hline & range & $2.5-3.7$ & $2.8-4.5$ & $0.5-1.0$ & $1.1-1.4$ & $15-20$ \\
\hline \multirow{2}{*}{ Sig lake, Tver Oblast $(\mathrm{n}=8)$} & mean & $3.2 \pm 0.2^{\mathrm{d}}$ & $3.3 \pm 0.2$ & $0.7 \pm 0.1^{\mathrm{d}}$ & $0.9 \pm 0.1^{\mathrm{d}}$ & $13.9 \pm 1.1^{\mathrm{d}}$ \\
\hline & range & $3.0-3.5$ & $3.0-3.9$ & $0.5-0.9$ & $0.7-1.1$ & $13-16$ \\
\hline \multirow{2}{*}{ Sabro lake, Tver Oblast $(n=4)$} & mean & $2.5 \pm 0.2^{\mathrm{e}}$ & $2.5 \pm 0.1^{\mathrm{e}}$ & $0.9 \pm 0.1$ & $0.9 \pm 0.1^{\mathrm{e}}$ & $12.2 \pm 0.7^{\mathrm{e}}$ \\
\hline & range & $2.2-2.8$ & $2.3-2.7$ & $0.7-1.1$ & $0.7-1.0$ & $11-14$ \\
\hline \multirow{2}{*}{ Riumnikovo lake, Yaroslavl Oblast $(\mathrm{n}=5)$} & mean & $3.0 \pm 0.3$ & $3.0 \pm 0.3$ & $0.8 \pm 0.2$ & $1.1 \pm 0.1$ & $14.8 \pm 0.9^{f}$ \\
\hline & range & $2.5-3.4$ & $2.3-3.5$ & $0.5-1.0$ & $0.7-1.3$ & $14-16$ \\
\hline \multirow{2}{*}{$\begin{array}{l}\text { Rybinsk Reservoir, the Volga stretch, } \\
\text { Yaroslavl Oblast }(n=4)\end{array}$} & mean & $2.2 \pm 0.2^{\mathrm{g}}$ & $2.5 \pm 0.1^{\mathrm{g}}$ & $1.1 \pm 0.1^{\mathrm{g}}$ & $1.1 \pm 0.1^{\mathrm{g}}$ & $11.4 \pm 0.5^{\mathrm{g}}$ \\
\hline & range & $1.8-2.7$ & $2.3-2.8$ & $1.0-1.5$ & $0.9-1.2$ & $11-12$ \\
\hline
\end{tabular}

Note: $\mathrm{L}_{\mathrm{fr}}$ - fruit length $(\mathrm{cm}), \mathrm{D}_{\mathrm{fr}}-$ fruit diameter $(\mathrm{cm}), \mathrm{L}_{\mathrm{nfr}}-$ length of the fruit's neck $(\mathrm{cm}), \mathrm{D}_{\mathrm{sf}}-$ diameter of the stigma of the fruit $(\mathrm{cm}), \mathrm{N}_{\mathrm{sr}}-$ number of rays of stigmas of fruit; differences are statistically significant at $\mathrm{P}<0.05$ (with Tukey test and Bonferroni correction) between the selections: $\mathrm{L}_{\mathrm{fr}}-\mathrm{a}-\mathrm{g}, \mathrm{b}-\mathrm{g}, \mathrm{d}-\mathrm{g}, \mathrm{b}-\mathrm{e}$; $\mathrm{D}_{\mathrm{fr}}-\mathrm{c}-\mathrm{e}, \mathrm{c}-\mathrm{g} ; \mathrm{L}_{\mathrm{nfr}}-\mathrm{d}-$ $\mathrm{g} ; \mathrm{D}_{\mathrm{sfr}}-\mathrm{c}-\mathrm{d}, \mathrm{c}-\mathrm{e}, \mathrm{c}-\mathrm{g} ; \mathrm{N}_{\mathrm{sr}}-\mathrm{a}-\mathrm{c}, \mathrm{b}-\mathrm{c}, \mathrm{c}-\mathrm{d}, \mathrm{c}-\mathrm{e}, \mathrm{c}-\mathrm{f}, \mathrm{c}-\mathrm{g}$.

While analyzing the data given in Table 1 , we should note that the inter-lake differences in some morphological parameters of the fruits were most notably manifested between the Belarus lakes and a number of lakes (Sig, Sabro and Ruimnikovo) and the Volga stretch of Rybinsk Reservoir (RR), Sig lake and the Volga stretch of Rybinsk Reservoir (RR). Between all the rest of the selections, no morphological differences of the fruits were observed. At the same time, most morphological parameters of fruits from Sabro Lake and the Volga stretch of the Rybinsk Reservoir (Table 1) were reliably lower than the similar values of the lakes they were compared with.

Intraregional differences in separate morphological parameters of the fruits were most notably manifested only in the Belarus lakes. Therefore, the reliable differences by number of rays of the stigma were observed between Mlynok and Skripovo lakes $(\mathrm{P}=0.0240)$ and Vydrennik and Skripovo lakes $(\mathrm{P}=0.0003)$. In Skripovo Lake, this parameter was significantly more notable than in the other two lakes (Table 1).

The data on seed productivity of the fruits of $N$. lutea in the center of European Russia and the Republic of Belarus are presented in Table 2. Their analysis revealed absence of reliable differences between the fruits from different lakes. It is noteworthy that according to our data the seed productivity of yellow water lily from the Rybinsk Reservoir of Yaroslavl Oblast (Volga stretch, Table 2) is close to such parameters of this plant from the Uglich Reservoir of Tver Oblast (296 \pm 81.4, ranging $83-446, n=12$ ). We should note that in peat soils the number of seeds in fruits of $N$. lutea reached $242 \pm 67$, in muddy soil $-296 \pm 81$, in sandy soils $-179 \pm 13$ (at the same time, the differences were reliable at $\mathrm{P}<0.05$ only between muddy and sandy soils, $\mathrm{P}=0.0491$ ).

Fruits of $N$. lutea ripen on the surface of water. By the end of the period of ripening of the fruits, in the lower part of the pericarp the remnants of petals (which change their colour from yellow to green as the fruit ripens) and stamens still remain. During ripening, the fruit separates from the lower part of the pericarp and sometimes stays on the water. Over that period, the external cover (pericarp) of the fruit cracks open.

Our observations show that the external shell of the fruit of yellow water lily begins to crack at the base of the fruit, at the same time its external membranes turn out, which in turn contributes to the release of mericarps closely located one to another. Their number in $N$. lutea often coincides with number of rays on the stigma. The mericarps are elongated-triangular segments which contain seeds. They can often contain underdeveloped seeds or no seeds at all. The mericarps with slimy walls and air bubbles can for a short time float on the water surface. In the territory of European Russia this process can be seen in late July and late August.

\section{Table 2}

Seed productivity of the fruits of $N$. lutea in the central part of European Russia and the Republic of Belarus $(\mathrm{x} \pm \mathrm{SD})$

\begin{tabular}{|c|c|c|}
\hline Water bodies & & Seed productivity \\
\hline \multirow{2}{*}{ Mlynok lake } & mean & $192.6 \pm 40.5$ \\
\hline & range & $97-256$ \\
\hline \multirow{2}{*}{ Vydrennik lake } & mean & $246.2 \pm 81.2$ \\
\hline & range & $98-445$ \\
\hline \multirow{2}{*}{ Skripovo lake } & mean & $268.6 \pm 52.8$ \\
\hline & range & $173-380$ \\
\hline \multirow{2}{*}{ Sig lake } & mean & $191.0 \pm 14.5$ \\
\hline & range & $169-216$ \\
\hline \multirow{2}{*}{ Sabro lake } & mean & $181.4 \pm 12.1$ \\
\hline & range & $163-204$ \\
\hline \multirow{2}{*}{ Riumnikovo lake } & mean & $242.6 \pm 39.3$ \\
\hline & range & $183-307$ \\
\hline \multirow{2}{*}{ Rybinsk Reservoir, the Volga stretch } & mean & $289.6 \pm 81.1$ \\
\hline & range & 104435 \\
\hline
\end{tabular}

Note: the number of analyzed fruits, parameters and the indications are the same as in Table 1.

In our experiments, conducted in the laboratory conditions, the release of the seeds from mericarps was observed during 2-3 hours. Then, most of the seeds of $N$. lutea $(70 \%$ and some with gradually decomposing mericarps) sunk to the bottom of the laboratory cups, and the rest of seeds $(30 \%)$ remained on the water surface until the end of the experiment (30 days). In the laboratory conditions, regardless of the terms of maintenance and character of stratification, the seeds germinated non-uniformly and singularly. Therefore, the final germination of the freshly-collected seeds of $N$. lutea which were kept 4 months in the freezer was very low 
(Table 3). Then, singular germinated seeds were observed only after dry cold stratification in the fridge ( 4 months). When kept for over 4 months (in different conditions) no seeds germinated.

Table 3

Parameters of germination of seeds of $N$. lutea $(\mathrm{x} \pm \mathrm{SD}, \mathrm{n}=30)$

\begin{tabular}{lrrrc}
\hline Parameter of & Freshly- & \multicolumn{3}{c}{ Period of stratification 4 months } \\
\cline { 2 - 5 } germination & collected & freezer & refrigerator laboratory conditions \\
\hline $\mathrm{L}$, days & $20.0 \pm 2.0$ & $3.3 \pm 2.2$ & - & - \\
$\mathrm{P}$, days & $3.0 \pm 2.6$ & $1.0 \pm 0.0$ & - & - \\
$\mathrm{G}_{\text {fin, }} \%$ & $4.4 \pm 1.4$ & $2.2 \pm 1.4$ & - & - \\
\hline \multicolumn{4}{l}{ Note: "-"-seeds did not germinate. } &
\end{tabular}

Initial stages of ontogenesis of $N$. lutea individuals of generative origin occurred in the following way.

Latent period. Seeds of were almost smooth, glossy, ellipsoid or reverse egg-like shape, often slightly oblate at the sides, with a longitudinal outline turned towards the medial part of the testa, yellow-brownish, green-brownish, dark-brownish, or brownish in colour, up to $0.48 \pm$ $0.10 \mathrm{~cm}$ in length and $0.26 \pm 0.10 \mathrm{~cm}$ in diameter. At the basal part of seed, there is a truncated top with rounded cap of $0.9 \pm 1.0 \mathrm{~mm}$ diameter. Embryo of $N$. lutea is straight, widely-conic in the apical part; has a well-developed bud, two cotyledons and hardly notable radicle.

Seedling $(p)$. This age state, in laboratory conditions, lasted over 20 days. Germination of fruits of $N$. lutea occurs underground as follows: the cotyledons begin to lengthen, thus bursting the cap outside. With further lengthening of the cotyledons, the basal part of the embryo with embryonic root comes out through the hole in the seed. At the same time, the apical parts of the cotyledons remain submerged in the endosperm throughout the period of their existence, performing gaustorial function. The cotyledons which fused at the base, cover the terminal bud of the embryo. The hypocotyl $(0.03 \pm 0.01 \mathrm{~cm}$ in length) followed by embryonic root $(0.05 \pm 0.01 \mathrm{~cm}$ in length) is manifested poorly. The place where the hypocotyl transforms into embryonic root is characterized by serrated crown-like thickening.

On the 3-4th day, in the seedlings, a non-petiole sheathed leaf (3.62 $\pm 0.90 \mathrm{~cm}$ in length) develops, having subulate shape. The moment of its appearance is followed by active development of the epicotyl, which gradually increases in length. We observed death of subulate leaf in plants by the $45-49$ th days.

By the end of the 7-8th days, the first normal developed leaf emerged, having a petiole and leaf lamina. Its unfolding occurs usually at $9-10$ days. This leaf was shifted by $180^{\circ}$ in relation to the first (subulate) leaf. The leaf lamina in that leaf was narrow-lancet, or narrowrhombic, with entire margins, light-green, thin, smooth, with clearly manifested central and several side veins. The unfolding of the first normal leaf implicates the emergence of the first inter-node adventitious root located within the first metamer of the developing rosette. We noted that usually the adventitious root was the longest, and the length of the subsequent adventitious roots varied on the unimodal curve. The length of the main root equals $0.83 \pm 0.50 \mathrm{~cm}$. In some cases the main root does not develop at all and dies.

By the end of the first - beginning of the second week of the seedling's development, the epicotyl significantly increases in size, reaching $0.15 \pm 0.06 \mathrm{~cm}$ in length and up to $0.1 \mathrm{~cm}$ in diameter. Growth of the hypocotyl, in this case, is significant, because particularly its bend causes change in the direction of growth of the main axis of the seedling in space - from orthotropic to anisotropic. At the same time, the hypocotyl continues to develop, increasing to $0.03 \pm 0.01 \mathrm{~cm}$ in length and 0.08 $\mathrm{cm}$ in diameter

Two weeks after the germination begins, unfolding of the second normal leaf takes place $(1.43 \pm 0.24 \mathrm{~cm}$ in length), the leaf lamina of which is widely-lancet or egg-like in shape. All the following leaves, which form on the area of the rhizome, are arranged spirally and partly overlap one another. During that period, the second adventitious root begins to form.

By the 20th day, in laboratory conditions, the cotyledon leaves die but remain connected to the plant for quite a long while. In the natural conditions this relation ruptures much earlier. The plant bears four leaves and two adventitious roots. The third normal leaf $(3.16 \pm 0.69 \mathrm{~cm}$ in length), similarly to all described earlier, is submerged, cordate ar- row-shaped, with entire margins, light-green, semi-transparent, undulate at the margin. The capacity of the apical bud at this stage of the development of the plant reaches around $4.3 \pm 0.4$ primordial leaf. The main root reaches its maximum sizes (Table 6).

Therefore, by the end of this age state, the seedling is anisotropically growing rosette shoot (with three inter-nodes which grow in diameter in the basal area), bearing 4 assimilating leaves or 2 non-ramifying adventitious roots (Table 4 ).

Table 4

Morphological parameters of the elements of the shoot sphere of seedling of $N$. lutea

\begin{tabular}{llc}
\hline \multicolumn{1}{c}{ Organ of seedling } & Morphologic parameters & Sizes, cm. \\
\hline \multirow{2}{*}{ Hypocotyl } & Length & $0.08 \pm 0.03$ \\
& Diameter & $0.12 \pm 0.02$ \\
Epicotyl & Length & $0.13 \pm 0.03$ \\
The main root & Diameter & $0.12 \pm 0.01$ \\
Adventitious root 1 & Length & $3.85 \pm 1.72$ \\
Adventitious root 2 & Length & $9.27 \pm 3.68$ \\
The first subulate leaf & Length & $8.91 \pm 3.43$ \\
& Length & $3.62 \pm 0.90$ \\
& Length of petiole & $1.56 \pm 0.48$ \\
& Length of sheathed part & $0.42 \pm 0.07$ \\
& Length of lamina & $2.17 \pm 1.06$ \\
& Width of lamina & $0.88 \pm 0.38$ \\
Petiole leaf & Length of petiole & $1.43 \pm 0.24$ \\
& Length of sheathed part & $0.40 \pm 0.07$ \\
\multirow{2}{*}{2} & Length of lamina & $2.07 \pm 0.64$ \\
& Width of lamina & $1.11 \pm 0.51$ \\
& Length of petiole & $1.34 \pm 0.17$ \\
& Length of sheathed part & $0.40 \pm 0.04$ \\
& Length of lamina & $2.23 \pm 0.29$ \\
B 3 & Width of lamina & $1.55 \pm 0.74$ \\
& Length & $0.09 \pm 0.03$ \\
& Diameter & $0.11 \pm 0.02$ \\
\hline
\end{tabular}

Juvenile plants (j). Duration of age state fluctuates and depends on the time of formation of the first floating leaf.

The shoot continues to grow monopodially and orthotropically, being observed to have active development of the basal rosette region (Table 2). By the end of the first year of the development it is represented by 9 shortened internodes. The length of the basal area (not taking into account the epicotyl and hypocotyl) of the rosette shoot reaches $0.46 \pm 0.08$ and $0.26 \pm$ $0.06 \mathrm{~cm}$ in diameter. At the same time, in the lower part of the rosette shoot, scars from 2-3 dead leaves are seen. At the same time, we observed complete death of hypocotyl and epicotyl. The capacity of the apical bud of the shoot comprised $4.5 \pm 0.5$ primordial leaf.

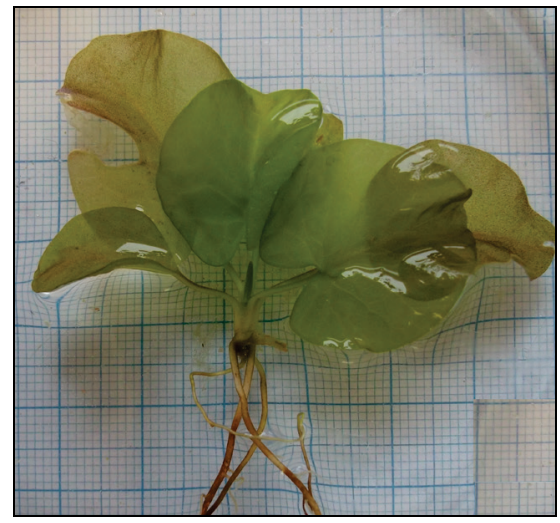

Fig. 2. Juvenile plant of $N$. lutea in the conditions of the experiment

According to our observations, by the end of the first year of the development (fifth - beginning of the sixth month) the plants formed 1112 leaves (around 2-3 of them died). We observed complete death of the second leaf by the days 115-129, the third leaf in most plants died by the days $140-150$. The major mass of the leaves comprised submerged, cordate arrow-shaped, with entire margins, light green, semitransparent leaves, and leaves with undulate margin. Nonetheless, sometimes in the apical part of the buds, heart-shaped, rougher leaves can 
be present, therefore the margins are straight, not undulate. All the parameters we measured in leaves (total length of leaf, length of the leaf sheath, length of the petiole, length and width of the leaf lamina) located towards the acropetal direction, gradually increased (to 6 leaves inclusively), and then the values of these parameters naturally reduced. At the same time, the sizes of the seventh and the subsequent leaf laminae usually did not exceed $1.32 \pm 0.24 \mathrm{~cm}$ in length and $1.54 \pm 0.20 \mathrm{~cm}$ in width. The axillary buds were absent. Furthermore, at the base of the apical bud and several opened leaves, hairs were present, represented by one row of thin-walled cells with transparent contents, which are interconnected.

In general, by the end of vegetation season, on the plant, 5-6 adventitious roots can form; usually 2 of them die. At the same time, the first adventitious root dies 1.5 months after the beginning of its development, while the second - after 2.0-2.5 months. The young roots are of white colour, old roots have orange-brownish tone. It should be noted that the first two adventitious roots do not ramify, and the ramification of the subsequent adventitious roots can reach $n+1$ and $n+2$ orders. Change in the linear sizes of the roots takes place along the unimodal curve. Maximum length of live roots at this stage of ontogenesis reaches $10.5 \pm 2.0 \mathrm{~cm}$ (diameter at the base $-0.8 \pm 0.1 \mathrm{~mm}$ ).

Therefore, by the end of the first year of development, the juvenile plants are anisatropically growing rosette shoots, bearing 11-12 leaves and 5-6 adventitious roots which ramify to $n+1$ order. We observed such plants in large amounts on the bottom of the Korozhechna River near Masalskoe village.

\section{Discussion}

The data on size characteristics of the fruits of yellow water lily are very poor. Thus, Dubyna (1982) has demonstrated that in aquatic objects of the former Ukrainian SSR, the jug-like, sometimes bottle-shaped fruit of this species is $4.5-7.0 \mathrm{~cm}$ in length and $3.0-5.0 \mathrm{~cm}$ in diameter, and the diameter of stigma disk reaches $1.43 \pm 0.03 \mathrm{~cm}$. At the same time, he distinguished $N$. lutea (var. luteum Countinho,1892 and var. urceolatum Casp., 1857), having close values for length, diameter of the fruit and diameter of the stigma (Dubyna, 1982). These results, compared to our data (Table 1), demonstrate that significant differences were observed only for length of the fruit, which in Ukrainian plants was 1.5 times higher. This is confirmed by the materials by Chernova (2013) who compared aquatic, semi-aquatic and terrestrial forms of yellow water lily from Yaroslavl (the Ild River) and Voronezh Oblasts (the Bolshoe, Osinovskoe, Maloe Podpesochnoe and Sadilka lakes). She has shown that by the length of the fruit, significant differences between different ecological forms of Yaroslavl plants were absent. A different picture was observed for the other two parameters - diameter of fruit and stigma. Here, the reliable differences were observed between the parameters of aquatic and semi-aquatic, and also semi-aquatic and terrestrial forms. By contrast, different forms of the Voronezh plants were observed to have significant differences in length of the fruit, and also the diameter of fruit and stigma (between aquatic, semi-aquatic and terrestrial forms) (Chernova, 2013).

The differences indicated in the study for number of size characteristics of the fruits of yellow water lily in different aquatic objects are likely to be associated with differences in the growing locations by content of nutrients in water and soil. As indicated by the French researchers (Henriot et al., 2019), habitat rich in nutrients does not always positively affect the growth and reproductive characteristics of yellow water lily. Therefore, Henriot et al. (2019), for example report that nutrient-rich growing locations can have unfavourable effects on species if the anoxia becomes so high that the species is not able to cancel out its negative effect through oxygenation of the rhyzosphere.

As noted by Heslop-Harrison (1955), the total number of seeds in the fruit is a variable. Such differences can be genetically-caused and depend on the weather conditions, pattern of the habitat and efficiency of pollination (Heslop-Harrison, 1955; Lippok et al., 1997; Chernova, 2013). Therefore, for example, Chernova (2013) reported that the number of seeds per fruits decreases during the transition from the aquatic form of the water lily to the terrestrial form. Significant positive correlation was already discovered earlier between the increase in phosphorus and organic carbon in water and number of flowers and seeds of the yellow water lily. By contrast, reproductive success and productivity of $N$. lutea reduces when the plant faces stress related to lack of nutrients (Henriot et al., 2019). Furthermore, scientists have demonstrated that the composition of the bottom deposits (unlike the water content) affects the main characteristics of the yellow water lily to a lower extent. Nonetheless, the number of seedlings and seeds, as well as diameter of the rhizome of $N$. lutea negatively correlated with the concentration of nitrogen along all the depth of the bottom deposits (Henriot et al., 2019).

Comparing the seed productivity of the yellow water lily and other species of water lilies, we should note that according to our data this parameter for the rare species for the European Russia - N. pumila (Timm) DC. in the territory of Tver Oblast (the Kezadra lake) equaled 110.6 \pm 24.5 seeds for fruit. Even lower is the seed productivity of this species in Japan, where it as rare as in our country and is represented by two forms: subsp. pumila (46.0 \pm 39.0 seeds per fruit, Lippok \& Renner, 1997) and subsp. oguraensis (Miki) Padgett (39.9 \pm 20.3 , variance range $-17-90)$ (Padgett et al., 2002).

Fruit of $N$. lutea is represented by spongy syncarpous berry-like multifolliculus (Chernova, 2013). According to Dubyna et al. (1993), the duration of the period of ripening of the fruit reaches $35 \pm 4$ days, and the duration of the ripening of the fruits in the first half of the summer (compared to the second) reduces by 5-10 days. Often during the ripening, the fruit separates from the lower part of the pericarp, and then can drift for 23 days (Heslop-Harrison, 1955; Fer \& Hroudova, 2008), being carried large distances by the water flows. This was also confirmed by our observations. Then, the fruits of $N$. lutea undergo cracking of the external coverpericarp and release of mericarps which open hydrochazically (Abizov \& Tolkachev, 2016). Similarly to the small part of the seeds released from mericarps, the mericarps of $N$. lutea themselves can for a short period remain floating. A similar picture was earlier described by American scientists (Hart \& Cox, 1995) who noted dispersal of the seeds of yellow water lily on the surface of water (despite their negative buoyancy) in the glacial lakes of the Rocky Mountains in the West of the USA in two different ways: inside the floating fruits and inside floating but water-soluble matrix (probably indicating mericarps) which surrounds the seeds. The first way causes group dispersal of seeds, the second - scattered dispersal, when the fruits and seeds can move on the surface of water with the speed of up to $80 \mathrm{~m} / \mathrm{h}$ (Hart \& Cox, 1995).

We demonstrated that the seeds from $N$. lutea differ by duration and period of floating on the water surface. Such peculiarity was for the first time noted by Dutch scientists during studies on the buoyancy of the fruits of Sparganium emersum Rehm., which they named "bimodal dispersal strategy" (terminology of Pollux et al., 2009). In this case, this peculiarity can be associated with, first of all, large volume of the embryo itself, as well as presence of grains of starch in the epiderm of the testa, and aleuronic grains and additional fats, necessary for the development of the embryo, in the endosperm (Abizov \& Tolkachev, 2016). We should note that "bimodal dispersal ability" was observed earlier for hygrophytes, for example in three species Ranunculus L. ( $R$. circinatus Sibth., R. kauffmanii Clerc and $R$. trichophyllus Chaix) (Lebedeva \& Lapirov, 2013). Researchers (Lebedeva \& Lapirov, 2013) have shown that in the experimental conditions the major part of the achenes $(\sim 80 \%)$ from these plants can remain on the water surface for up to 90-110 days, while the rest sank to the bottom of the laboratory cups over 1-2 days.

Among the dominating "dispersing modes" (terminology of Sádlo et al., 2018), N. lutea prefers hydrochoria - distribution of fruits and seeds by water currents. In the lake ecosystems, there was also observed the process of anemohydrochoria - spread of fruits and seeds over the water surface by air flows. The literature data on the dispersal of the seeds of $N$. lutea vary. Therefore, Dubyna (1982) reports a distance of 8-10 km, the data of Abizov \& Tolkachev (2016) indicate the distribution of seeds across 5-20 and more km, Fer \& Hroudova (2008) - $25 \mathrm{~km}$. It seems that the distance of dispersal of the seeds is limited directly by the speed of the water flow (Dubyna, 1982). Based on their observations, Fer \& Hroudova (2008) think that distribution of most seeds of Nuphar from the upper reach to the lower reaches occurs most often in the period of freshets rather than during the ripening of the seeds in the vegetation period. Earlier, Hart \& Cox (1995) reported that though seeds of yellow water lily float only during $72 \mathrm{~h}$, this time is enough for dispersal, especially in small glacial lakes connected by watercourses. Despite high parameters of the germination of seeds of $N$. lutea obtained by a number of authors ( $80-$ 
100\%, Manohina, 1977; Abizov \& Tolkachev, 2016), we did not achieve similar (or close) results even after the 4, 8 and 12-month stratification. In our opinion, the seeds that we collected at the end of the first decade of August of 2018 in the lake extension of the Korozhechna River were in the state of endogenous (organic) morphophysiological intermediate-type rest (Nikolaeva et al., 1985) caused by the combination of the morphologically and anatomically underdeveloped condition of the embryo and specific physiological condition (reduced growth activity and insufficient gas-penetrability of the surrounding tissues). The results given in the study by Smits et al. (1990) indicate that the seeds of yellow water lily in the state of physiological rest do not germinate until the environmental conditions become favourable for seedling emergence. An opposite opinion exists. Nikolaeva et al. (1999) consider that organic type of rest is characterized by decrease in germination or complete absence of germination even in favourable conditions. This in particular occurred in our case when the increase in the germination parameters was not achieved even after long cold dry stratification. Furthermore, the seeds of $N$. lutea are sensitive to drying (Smits et al., 1989), which can limit their ability to germinate. One should also take into account that a seed's undergoing of all typical phases of the development directly depends on the condition of the endosperm. At the early stages of the development it provides the embryo not only with nutrients, but functions as the source of phytohormones, thus affecting the course of the development of the embryo (Nikolaeva et al., 1999). The water lily belongs to plants in which the main reserve-accumulating tissue is perisperm, while the endosperm is poorly differentiated and remains only near the small embryo (Nikolaeva et al., 1999), which can delay the germination. In any case, in natural conditions such ability ("postpone germination, terminology of Smits et al., 1990) is an important adaptive tool which ensures the portioned and prolonged development of seeds (Kroker \& Barton, 1955; Lapirov, 2015) and thus the survival of the species. At the same time, Smits et al. (1990) think that $N$. lutea has a temporal bank of seeds with all vital seeds which germinate within a year, whereas Heslop-Harrison (1955) discovered that some of the seeds can remain vital in the seed bank and germinate in the following years. However, in natural conditions the vegetative reproduction of yellow water lily prevails over the generative, and seed reproduction occurs in favourable conditions (Fer \& Hroudova, 2008).

Taking into account the low parameters of germination of the seeds of yellow water lily which we obtained in the laboratory conditions, especially interesting is the issue of possibility and pattern of the development of seedlings from them, especially at the initial, the most important stages of the plant's development. As our surveys and observations showed, the development of the plant at the initial stages of ontogenesis had no significant differences from the development in the natural environment, where quite often the seedlings of terrestrial and submerged forms of $N$. lutea were seen. The significant number of discovered seedlings of the surveyed species is reported also in the data by other authors (Heslop-Harrison, 1955; Dubyna, 1982). Dubyna (1982) mentions that in nature the germination of nymphaeid seed is observed throughout the vegetation season and has a periodic pattern. Therefore, in spring, the germination begins in April and continues until May, in summer it lasts from late July to late August, in autumn - from September until frosts (Dubyna, 1982). We observed the latter numerously in the conditions of Yaroslavl, Tver and Nizhegorod Oblasts.

Our data on morphology of the plants at the initial stages of ontogenesis are in accordance with the materials of other researchers (Dubyna, 1982; Richards \& Cao, 2012; Abizov \& Tolkachev, 2016). As we mentioned earlier, at the stage of seedling, the plant's first subulate leaf develops. Dubyna (1982) reports that the length of the leaf of such type directly depends on the illuminance and depth of water. This leaf locates at the angle of $90^{\circ}$ towards the cotyledon. Initially it is has no chlorophyll, but under the influence of light quickly obtains green colour with inclusions of red pigment. We think that the functions of this leaf are similar to the functions of coleoptile in the cereals. Turdiev (1960) reported the significant role of the subulate leaf at the initial stages of the development of a seedling, calling it the first assimilating organ and attributed the function of protection of the terminal bud of the seedling to it. Our data on the duration of life of the subulate leaf coincide with the data of Turdiev (1960), who observed death of the subulate leaf in $N$. lutea on days 30-45. Dubyna (1982) reports that with seedlings submerged to the depth of $10-15 \mathrm{~cm}$, the subulate leaf functioned only around 7-10 days, whereas at greater depths its existence was prolonged almost twice as much (15-25 days). Perhaps, the duration of functioning of leaf of such type in the natural condition depends also on the temperature of the water.

As was justifiably noted by Abizov \& Tolkachev (2016), ontogenesis of $N$. lutea can be characterized by significant polyvariance implicated by the peculiarities of formation of the plants (terms of transition of the plants to the subsequent age state) from generative and vegetative embryos and ecological conditions of a particular growing location (chemical composition of water, temperature regime, density of population). For example, this is indicated by the fact that with increase in the depth of growth of seedlings of $N$. odorata (close to Nuphar in the systematic aspect) the increase in the length of hypocotyl is observed, at the same time the decrease in the length of the main root and sizes of leaves is seen (Richards $\& \mathrm{Cao}, 2012$ ). In the following stages of ontogenesis (juvenile and immature plants), at increase in the depth of growing of the plant, growth of petioles and sizes of the leaf lamina was observed (Richards \& Cao, 2012), which was likely caused by low illuminance for plants at the bed. The fact that the number of leaves on the shoot which develop during the vegetative season in young individuals of vegetative origin directly depends on the nutrient composition of soil is also indicated in the data by Dubyna (1982).

Our data on the duration of juvenile age state in plants significantly differ from the data by Abizov \& Tolkachev (2016). These authors report that this age state lasts for 10-14 days. Our observations indicate longer terms. We should note that the formation of the first floating leaf contributing to the transition of the plant to immature age state can be observed both by the end of the first year of the development and at the beginning of the second. In the study by the mentioned authors, the transition into the immature age state is associated mainly with the change in the pattern of growth of the rosette shoot from orthotropic to anisotropic. In the conditions of the culture, we demonstrated that by the end of ontogenetic state of the seedling, one can observe this change in the pattern of growth of the rosette shoot. We should note that the appearance of the first above-water leaves in the plants in the Pahra River, as reported by Abizov \& Tolkachev (2016), is characteristic of only adult vegetative plants (virginile age state) which is not entirely correct. Appearance of the first floating leaves was observed in the end of the first or the second year of life of the plant. Transition to the immature age state is characterized by the presence of ramification of the shoot system, not mentioned by Abizov \& Tolkachev (2016). Thus, except for everything mentioned above, we observed the differences in time of undergoing the ontogenetic phases in plants of $N$. lutea which grow in natural conditions and the conditions of cultivated plants, beginning from the juvenile ontogenetic state.

Despite the good germination ability of seeds of $N$. lutea in natural conditions, seed plants of the second and the third year of the development are found extremely rarely. In our opinion, this is first of all related to the freezing of the water body and the abrasion and silt-driven drifts of young plants in the period of high water. Having not observed such plants in water bodies, Heslop-Harrison (1955) presumed that high mortality of the seedlings was related to low illuminance - the main development-restricting factor for the plants which depend on the depth and transparency of water.

\section{Conclusions}

Our surveys revealed that significant differences in a number of size characteristics of the fruits of yellow water lily are most notably manifested between the Belarus lakes and a number of lakes (Sig, Sabro and Riumnikovo) and the Volga stretch of the Rybinsk Reservoir, and also the Sig lake and the Volga stretch of the Rybinsk Reservoir. At the same time, most morphological parameters of the fruits from Sabro Lake and the Volga stretch of the Rybinsk Reservoir (Table 1) were reliably lower than the similar values of the lakes which they were compared with. Intraregional differences in morphology of the fruits (number of rays of the stigma of the fruit) manifested most notably only in the Belarus lakes. All this confirms our opinion on the impact of ecological conditions of germination on the sizes of fruits, and also the formation of seeds and their number. It seems that the seed productivity, as well as morphological peculiarities of fruits can depend on a number of internal and external factors. At the same time, their influence is not always positive. 
The possibility of dispersal of seeds of $N$. lutea over long distances is due not only to the buoyancy of the seeds itself, but the "multi-step" process of their release - at first, the mericarps are released from the fruits, and then seeds from the mericarps. At the same time, the fruits, mericarps and seeds float for some time on the water surface. Such ability allows them to prolong the process of dissemination, and therefore allows the seeds to spread greater distances from the mother plant.

In our experiments the low germination ability of the seeds both freshly-collected and those after different terms of dry stratification is due to the condition of the endogenous (organic) morpho-physiological intermediate type of rest. The presence of this type of rest in natural conditions contributed to the formation of an ability of the plant in the natural populations which is very useful for adaptation, i.e. the mechanism of postponing germination, which enables seeds to grow in portions and over an extended period of time. At the same time, in the natural populations the vegetative reproduction of yellow water lily prevails over the generative, which is characteristic of most aquatic and shoreline plants.

The initial stages of ontogenesis of $N$. lutea are characterized by polyvariance in relation to the tempi of the development of the plant, which is expressed in different rates of the individual development (terms of transition of plant to the following age state) of generative diasporas in the natural conditions and aquarium conditions. In the case of $N$. lutea, obviously the morphological polyvariance of ontogenesis should manifest (as in the case of Nymphaea odorata), caused by the changes in morphological characteristics of the genet depending on the water level.

This work was carried out in the framework of the state budget topic No. AAAAA18-118012690099-2, "Vegetation of water bodies and watercourses in Russia: structure and dynamics" (head , candidate of biological sciences, associate professor A. G. Lapirov).

\section{References}

Abizov, E. A., \& Tolkachev, O. N. (2016). Ontogenez kubyshki zheltoy Nuphar lutea (L.) Smith (Nymphaeaceae Salisb.) [Ontogenesis of the Nuphar lutea (L.) Smith (Nymphaeaceae Salisb.)]. In: Netradicionnye prirodnye resursy, innovacionnye tekhnologii i produkty [Untraditional natural resources, innovation technologies and products], 24, 75-83 (in Russian).

Belyakov, E. A., \& Lapirov, A. G. (2015). Fruit germination of some representatives of the family Sparganiaceae Rudolphi under laboratory conditions. Inland Water Biology, 8(1), 33-37.

Belyakov, E. A., \& Lapirov, A. G. (2019). Seed productivity and peculiarities of floating of generative diaspores of some european species of the genus Sparganium L. Inland Water Biology, 12(2), S42-S48.

Bornette, G., \& Puijalon, S. (2011). Response of aquatic plants to abiotic factors: A review. Aquatic Sciences, 73(1), 1-14.

Borysiak, A., Borysiak, J., Joniak, T., \& Nagengast, B. (2011). Translocation of Nuphar lutea (L.) Sibth. \& Sm. from the A2 road near Nowy Tomyśl (Poland) into alternative sites. Biodiversity: Research and Conservation, 21, 63-72.

Chernova, A. M. (2013). Sravnitel'nyy analiz reproduktivnoy sfery Nuphar lutea (L.) Smith v menyayushchihsya usloviyah sredy [Comparative analysis of the reproductive sphere of Nuphar lutea (L.) Smith in changing environmental conditions]. Vestnik Tverskogo Gosudarstvennogo Universiteta, Seriya Biologiya i Ekologiya, 31(23), 123-132 (in Russian).

Chernova, A. M. (2015). Seasonal dynamics of yellow water lily Nuphur lutea (L.) Smith (Nymphaeaceae) in the small Il'd River (Yaroslavl oblast). Inland Water Biology, 8(2), 157-165.

Chernyak, D. M. (2018). A study of the seed productivity of Heracleum sosnowskyi Manden in the south of Primorsky Krai. International Research Journal, 74, 92-95.

Copenhaver, M. D., \& Holland, B. (1988). Computation of the distribution of the maximum studentized range statistic with application to multiple significance testing of simple effects. Journal of Statistical Computation and Simulation, 30(1), 1-15.

Dubyna, D. V. (1982). Kuvshinkovye Ukrainy [Nymphaeaceae from Ukraine]. Naukova Dumka, Kiev (in Russian).

Dubyna, D. V., Stoyko, S. M., Sytnik, S. M., Tasenkevich, L. A., Shelyag-Sosonko, Y. R., Geyny, S., Groudova, Z., Gusak, S., Otygelova, G., \& Erzhabkova, O. (1993). Makrofity - indikatory izmeneniy prirodnoy sredy [Macrophytes - indicators of changes of natural environment]. Naukova Dumka, Kiev (in Russian).

Elakovich, S. D., \& Wooten, J. W. (1991). Allelopathic potential of Nuphar lutea (L.) Sibth. \& Sm. (Nymphaeaceae). Journal of Chemical Ecology, 17, 707-714.
Fer, T., \& Hroudova, Z. (2008). Detecting dispersal of Nuphar lutea in river corridors using microsatellite markers. Freshwater Biology, 53, 1409-1422.

Gurnell, A. M. (2014). Plants as river system engineers. Earth Surface Processes and Landforms, 39(1), 4-25.

Hammer, Ø., Harper, D. A. T., \& Ryan, P. D. (2001). PAST: Paleontological statistics software package for education and data analysis. Palaeontologia Electronica, 4(1), 1-9.

Hart, K. H., \& Cox, P. A. (1995). Dispersal ecology of Nuphar luteum (L.) Sibthorp \& Smith: Abiotic seed dispersal mechanisms. Botanical Journal of the Linnean Society, 119(1), 87-100.

Henriot, C. P., Cuenot, Q., Levrey, L-H., Loup, C., Chiarello, L., Masclaux, H., \& Bornette, G. (2019). Relationships between key functional traits of the waterlily Nuphar lutea and wetland nutrient content. PeerJ - Journal of Life and Environmental Sciences, 7, e7861.

Heslop-Harrison, Y. (1955). Nuphar Sm. Journal of Ecology, 43(1), 342-364.

Kaplan, D., Oron, T., \& Gutman, M. (1998). Development of macrophytic vegetation in the Agmon wetland of Israel by spontaneous colonization and reintroduction. Wetlands Ecology and Management, 6(2-3), 143-150.

Klok, P. F., \& van der Velde, G. (2017). Plant traits and environment: Floating leaf blade production and tumover of waterlilies. PeerJ - Journal of Life and Environmental Sciences, 5, e3212.

Komarov, A. S., Palenova, M. M., \& Smirnova, O. V. (2003). The concept of discrete description of plant ontogenesis and cellular automata models of plant populations. Ecological Modelling, 170, 427-439.

Kroker, V., \& Barton, L. (1955). Fiziologiya semyan [Seed physiology]. Izdatelstvo Inostrannoy Literatury, Moscow (in Russian).

Lapirov, A. G. (2015). Ontogenez nazemnoy i pogruzhennoy form Alisma gramineum Lej. (Alismataceae) [Ontogeny of terrestrial and submerged forms Alisma gramineum Lej. (Alismataceae)]. Trudy Instituta Biologii Vnutrennih Vod Imeni I. D. Papanina Rossiyskoy Akademii Nauk, 71, 78-91.

Lebedeva, O. A., \& Lapirov, A. G. (2013). O rasprostranenii nekotoryh vidov shelkovnikov (Ranunculaceae) v vodoemah i vodotokah Yaroslavskogo Povolzh'ya [On spread of some species of Batrachium (Ranunculaceae) in streams of the Volga Region in the Yaroslavl Region]. Yaroslavskiy Pedagogicheskiy Vestnik, 3(2), 55-60 (in Russian).

Lippok, B., \& Renner, S. S. (1997). Pollination of Nuphar (Nymphaeaceae) in Europe: Flies and bees rather than Donacia beetles. Plant Systematics and Evolution, 207(3-4), 273-283.

Manohina, R. P. (1977). Vodnye rasteniya dlya oformleniya vodoemov v gorodah i poselkah Sredney Azii [Water plants for the design of reservoirs in cities and towns of Central Asia]. Stroitel'stvo i Arhitektura Uzbekistana, 2, 22-26 (in Russian).

Mjelde, M., Hellsten, S., \& Ecke, F. (2013). A water level drawdown index for aquatic macrophytes in Nordic lakes. Hydrobiologia, 704(1), 141-151.

Nikolaeva, M. G, Lyanguzova, I. V., \& Pozdova, L. M. (1999). Biologiya semyan [Biology of Seeds]. Nauchno-Issledovatel'skiy Institut Himii Sankt-Peterburgskogo Gosudarstvennogo Universiteta, Saint-Petersburg (in Russian).

Nikolaeva, M. G., Razumova, M. V., \& Gladkova, V. N. (1985). Spravochnik po prorashchivaniyu pokoyashchikhsya semyan [Handbook on Germination of Dormant Seeds]. Nauka, Leningrad (in Russian).

Notov, A. A., \& Zhukova, L. A. (2019). The concept of ontogenesis polyvariance and modern evolutionary morphology. Biology Bulletin, 46(1), 47-55.

Padgett, D. J. (2007). A monograph of Nuphar (Nymphaeaceae). Rhodora, 109(937), 1-96.

Padgett, D. J., Horky, L. A., \& Shimoda, M. (2002). Seed production and germination in endangered Nuphar (Nymphaeaceae) of Western Japan. Journal of Phytogeography and Taxonomy, 50, 35-40.

Padgett, D. J., Les, D. H., \& Crow, G. E. (1999). Phylogenetic relationships in $\mathrm{Nu}$ phar (Nymphaeaceae): Evidence from morphology, chloroplast DNA, and nuclear ribosomal DNA. American Journal of Botany, 86(9), 1316-1324.

Pollux, B. J. A., Verbruggen, E., van Groenendael, J. M., \& Ouborg, N. J. (2009). Intraspecific variation of seed floating ability in Sparganium emersum suggests a bimodal dispersal strategy. Aquatic Botany, 90(2), 199-203.

Richards, J. H., \& Cao, C. (2012). Germination and early growth of Nymphaea odorata at different water depths. Aquatic Botany, 98, 12-19.

Sádlo, J., Chytrý, M., Pergl, J., \& Pyšek, P. (2018). Plant dispersal strategies: A new classification based on the multiple dispersal modes of individual species. Preslia, 90, 1-22.

Savinykh, N. P., \& Cheryomushkina, V. A. (2015). Biomorphology: Current status and prospects. Contemporary Problems of Ecology, 8(5), 541-549.

Schoelynck, J., Bal, K., Verschoren, V., Penning, E., Struyf, E., Bouma, T., Meire, D., Meire, P., \& Temmerman, S. (2014). Different morphology of Nuphar lutea in two contrasting aquatic environments and its effect on ecosystem engineering. Earth Surface Processes and Landforms, 39, 2100-2108.

Smits, A. J. M., Avesaath, P. H. V., \& van der Velde, G. (1990). Germination requirements and seed banks of some nymphaeid macrophytes: Nymphaea alba L., Nuphar lutea (L.) Sm. and Nymphoides peltata (Gmel.) O. Kuntze. Freshwater Biology, 24(2), 315-326. 
Smits, A. J. M., de Lyon, M. J. H., van der Velde, G., Steentjes, P. L. M., \& Roelofs, J. G. M. (1988). Distribution of three nymphaeid macrophytes (Nymphaea alba L., Nuphar lutea (L.) Sm. and Nymphoides peltate (Gmel.) O. Kuntze) in relation to alkalinity and uptake of inorganic carbon. Aquatic Botany, 32, 45-62.

Smits, A. J. M., van Ruremonde, R., van der Velde, G. (1989). Seed dispersal of three nymphaeid macrophytes. Aquatic Botany, 35(2), 167-180.

Sütfeld, R., Petereit, F., \& Nahrstedt, A. (1996). Resorcinol in exudates of Nuphar lutea. Journal of Chemical Ecology, 22(12), 2221-2231.

Szankowski, M., \& Kłosowski, S. (1999). Habitat conditions of nymphaeid associations in Poland. Hydrobiologia, 415, 177-185.
Turdiev, S. Y. (1960). Nekotorye osobennosti prorastaniya semyan i formirovaniya prorostkov nimfeynyh [Some features of seed germination and formation of Nymphaeum seedlings]. Trudy Alma-Atinskogo Botanicheskogo Sada AN KazahSSR, 5, 164-178 (in Russian).

Tzvelev, N. N. (2000). Opredelitel' sosudistykh rastenij Severo-Zapadnoj Rossii (Leningradskaya, Pskovskaya i Novgorodskaya oblasti) [Manual of the vascular plants of North-West Russia (Leningrad, Pskov and Novgorod provinces)]. Saint-Petersburg State Chemical-Pharmaceutical Academy Press, Saint-Petersburg (in Russian).

Zbikowski, J., Kobak, J., \& Zbikowska, E. (2010). Is Nuphar lutea (L.) Sm. a structuring factor for macrozoobenthos and selected abiotic parameters of water and bottom sediments throughout the year? Aquatic Ecology, 44(4), 709-721. 